\title{
Ancient Greco-Roman Magic and the Agency of Victimhood ${ }^{1}$
}

\author{
Esther Eidinow \\ University of Nottingham, Department of Classics \\ Humanities, University Park, Nottingham NG7 2RD \\ esther.eidinow@nottingham.ac.uk
}

\begin{abstract}
Scholarship on ancient Greco-Roman "magic," over time and place, has largely focused on the role and identity of ritual practitioners, investigating the nature and source of their perceived expertise and often locating it in their linguistic skills. Less attention has been paid to those identified as the targets of magical rituals, who tend to be described as passive recipients of the ritual or the social power of another. In contrast, drawing on the theory of ritual form developed by Robert McCauley and E. Thomas Lawson, alongside the ritualization theories of Catherine Bell, this article argues that victims of magic were also agents of ritual. Focusing on an experience of hostile magic reported by the fourthcentury C.E. orator Libanius, it explores how conceptions of magical power were cocreated by spell-makers and their so-called victims and should be regarded as relational, that is, as emerging from the interactions of people and groups.
\end{abstract}

\section{Keywords}

magic - ritual - ritual form - ritualization - Libanius - Catherine Bell - Robert McCauley - E. Thomas Lawson

\section{Magic: The Role of the Victim?}

How did magic "work"? In scholarship on the practice of ancient magic, research into the perceived power of ancient Greco-Roman magic, be it archaic, classical, or Hellenistic, Republican or Imperial, has tended to focus on the role and activities of the ritual specialists or practitioners: for example, the manteis or magoi alluded to across different written sources, the largely unknown writers and/or authors of the corpus of binding spells, the intended users and/or the anonymous composers of the recipes in the Greek Magical Papyri. Much important work has been done to investigate the various indices of the expertise of such individuals. ${ }^{2}$ For example, there has been extensive discussion of how they may have identified themselves and/or were identified by others in particular communities and the rhetoric that encompassed their claims to, or others' ascriptions to them, of knowledge and power.

The ancient evidence indicates that such specialists might make assertions about the range and level of their own skills not only based on their own activities, but also reinforced by their claims to remarkable relationships, personal or professional, to families or clans of manteis or seers (see Flower 2008: 242; more generally on this topic,

1 The author would like to thank the anonymous reviewer for their extremely insightful and helpful comments.

2 It is of course impossible to cite all the relevant work here, and my references in this discussion will indicate only some works that I have found useful; the reader will no doubt wish to suggest others. This selectivity also applies to the citation and employment of work on ritual theory in the latter part of this article. 
see Frankfurter 1995, 1997, 2002, esp. 2002: 160-161). Alongside their own claims, many of those involved would, in turn, have been vocal in dismissing the abilities and capacities, and therefore the authority, of the teaching of others. We see examples of this rhetoric in, for example, the anonymous Hippocratic treatise On the Sacred Disease (see Lloyd 1979: 15-29, 86-98; Laskaris 2002) and the Derveni Papyrus (esp. col. 20; see Betegh 2004: 42-43).

In these claims and counterclaims, modern observers glimpse a highly competitive community; moreover, as the examples make clear, and as has long been observed in scholarship, it was one that did not neatly inhabit one (modern) category of activity. An extreme example of this phenomenon is offered by the pre-Socratic philosopher Empedokles, who may also be described as "a magician and a philosopher, a wonder-worker and a thinker" (Kingsley 1995: 231). The rhetoric concerning what was deemed acceptable or unacceptable religious activity and ensuing debates are part of a discourse that played an important part in the elaboration of the very concept of "magic" itself (e.g., Graf 1995; Dickie 2001; Carastro 2006 offers a useful reflection on the role played in this development by both the actual presence and the representation of the Persian magoi in ancient Greek culture). It suggests, as Richard Gordon has put it, with a vivid and effective image, how "the notion of magic ... was formed in the ancient world discontinuously and, as it were, with everybody talking at once" (1999: 163).

The theme of the power of speech is significant to this debate in other ways. Understandably, bearing in mind the extant sources, scholars of ancient magic have focused much of their exploration on what factors may endow a ritual specialist's language with power. Drawing on anthropological work in this area (such as, for example, Tambiah 1968), scholarship on the performativity of ancient magical action has tended to focus on this aspect. This includes, for example, the use of metaphor, simile, or analogy; ${ }^{3}$ the employment of historiolae (little mythic stories; see Frankfurter 1995); the use of nonsense words, words from other languages; or folklore motifs (Otto 2011: 160, 403-407; Versnel 2002). Some examination has been made of the performance of ritual and the ways in which this, too, may also have created a perception of "magical power." Again (and understandably, since these aspects must generally be elicited from descriptions), this approach also tends to return to language: it has raised the question of the role of performativity, particularly speech-act theory (Prins 1991; Giordano 1999), along with the potency of reversals and inversions. ${ }^{4}$ But there has also been some significant exploration of the role and symbolism of magical objects and materials (LiDonnici 2002; Boschung and Bremmer 2015). Altogether, such work on the perceived ritual competence of the agents of magical spells brings an increasingly rich understanding of ancient magic and its perceived power, both in its broader social context and with regard to specific examples.

The tendency of this research to focus on speech may be why, in contrast, relatively little attention has been paid to those perceived to be the victims or targets of magic. When they are discussed, it tends to be within a fairly limited remit. Usually, they appear as part of the examination of the aims of the practitioner. For example, Christopher Faraone describes how the terms of ancient erotic spells construct women, in particular, as desiring subjects (1999: 159-174), while I have discussed in my own

\footnotetext{
${ }^{3}$ See Collins 2008: 114-117, who offers a useful warning at the end of his analysis of the need for caution in interpretation.

${ }^{4}$ See, for example, Curbera 1999 on matronymics in ancient binding spells as an inversion of usual practice.
} 
work the targets of ancient binding spells as the foci of risks for those writing against them (2013: 143-236). Other scholars have noted how victims may become, in turn, practitioners, leading to what Daniel Ogden has vividly termed "a magical arms-race" (1999: 51-54, esp. 52). There is also some limited acknowledgment of a more active role played by victims in discussions of, for example, speculation about the emotional responses of individuals to specific situations of (erotic) anxiety or fear (see Tomlin 1988; Winkler 1990; Ogden 1999, esp. 82-85; some of these will be discussed in more detail below). However, in large part, these remain limited to speculations concerning individual psychology. This is notably different from anthropological (and historical) approaches to such questions, which, since E. E. Evans-Pritchard's 1937 ground-breaking work among the Azande, are commonly analyzed in terms of culturally specific beliefs in witchcraft, beliefs which are an integral part of a broader worldview. Thus, EvansPritchard described witchcraft as "a natural philosophy by which the relations between men and unfortunate events are explained and a ready and stereotyped means of reacting to such events" (1937: 63). ${ }^{5}$

One reason for the strikingly different approach of ancient historians is no doubt the nature of the ancient evidence: most of that which dates from the archaic to Hellenistic periods attributes personal or community misfortune to the displeasure of the gods rather than the magical attack of one's mortal enemies, although there are some striking exceptions to this (see Eidinow 2015: 67). This attitude begins to change in the Hellenistic era; as Gordon has argued, the Hellenistic period saw the development of a "strong notion of magic" (1999: 164). This may perhaps be taken as a further indication of the increasingly personal relationship with supernatural forces that is sometimes given as a characteristic of this era, although, as Matthew Dickie observes, while literary references to magic-working increase in this period, it is much more difficult to argue that there was actually greater practice of magic (2001: 93-96).

However we regard these developments, the result seems to be that most scholarship on ancient magic tends to overlook the victims in ways rather similar to the discourse of the ancient evidence itself. This seems to occur even in cases where scholars have observed that such an approach in the ancient text may be a deliberate rhetorical device intended to undermine the role of the victim, reinforce the power of others, and justify the social control of the former by the latter. For example, this argument has been made for the portrayal of women in early Christian texts dating to the second century C.E. ${ }^{6}$ Whether deliberately or not, such descriptions, ancient or modern, portray a victim as having lost agency - either in representation or in fact. The victim is not the only one who misses out: one of the effects of this approach is that modern observers are unable to gain a full picture of the ways in which magic "worked" in ancient cultures. This article onoffers a different approach to thinking about the victims of spells. It uses anthropological and cognitive theories to recast them as agents in what is, it argues, a process that itself generates the perceived power of magic.

In terms of agency, this article employs the categories put forward by Sherry Ortner (2006) - that is, the agency of power and the agency of projects. The former

\footnotetext{
${ }^{5}$ From among many, some well-known examples include Douglas 1970 and Favret-Saada 1980. Hutton 2004 provides an insightful review of the works in each discipline and the potential for collaboration between history and anthropology; witchcraft accusations are, of course, also a current political issue; see, for example, Schnoebelen 2009.

${ }^{6}$ See Stratton 2007: 111-114, who summarizes previous scholarship, including D’Angelo 1990, Burrus 1995, Cooper 1996; cf. Eidinow 2017.
} 
concerns a person's power to act for him or herself or on others, raising questions of domination and resistance; the latter describes a person's capacity to pursue their own intentions and desires, without involvement in situations of power, as defined above. Although the separation of these two categories is useful for heuristic purposes, in reality, their manifestations frequently overlap and interact. Using these terms, we can argue that in the current analysis of ancient magic, the focus is largely on issues of power and almost completely on the agency of power of the practitioner. This article argues that the agency of magical power, or, rather, the perception of that power, is created not only through the agency of the practitioner, but in addition through the agency of the victim. As Ortner has argued, "individuals or persons or subjects are always embedded in webs of relations, whether of affection and solidarity, or of power and rivalry" (2006: 151); the acquisition and exercise of agency is, thus, interactive and dynamic. In this sense, then, this article sets out to illustrate how "magic" and its perception is not a phenomenon that is activated by one person against another but, rather, should be regarded as a relational dynamic emerging from the interactions of people and groups. In that context, consideration of the role of the victim is important not only to further understanding of the ways in which individual rituals were perceived to occur. It also deepens our comprehension of the construction and maintenance of the overall plausibility of "magic" in the ancient world: that is, it moves us a little further towards an answer to the question of whether and, if so, how people believed in "magic."

This then, finally, is also the place to say something about my use of the term "magic." I will not attempt a definition of this notoriously difficult term: suffice it to say that, as is probably already apparent, I am employing it here, etically, to denote a specific category of ritual practice in which supernatural forces were somehow employed (be that harnessed, cajoled and persuaded, or forced) by one person to attack another. This use does also evoke the perception of the protagonist of the case study used later in this article: Libanius, the fourth-century C.E. orator for whom "magic ... was characterized by the use of body parts and dead animals and by the desire to do harm" (Sandwell 2007: 265). However, this use is not intended to imply either that this was the sole remit of this term as it is used in modern scholarship or that there were not many different emic terms for individual ritual practices, with nuances that distinguish them one from another and perhaps associate some more closely with more mainstream practices, such as prayer (see Versnel 1991b). In a number of my examples, the use of specific emic terms means that the identification of such activities is perhaps more secure. Studies of the development of the idea of magic in fifth to fourth-century B.C.E. Greece provide helpful insight into the difficulties of identifying and categorizing relevant activities in emic terms (see for example, Graf 1995; Dickie 2001). However, my aim with this article is that the analysis it presents should also be applicable across similar situations in which no such terms can be located. I think that the ample scholarship on the concept of "magic" suggests that there is general scholarly consensus in identifying which activities, across cultures, belong to such a category, drawing on cross-cultural patterns in ritual activities and the attitudes towards them. On this basis, I will be using evidence from across different ancient cultures and communities and referring to it here as "magic."

In what follows I begin with a consideration of recent scholarship's approach to the question of how magic works. My focus is on the broader category of ancient "curses," including both binding spells and prayers for justice, on the grounds that the ritual form is sufficiently similar, since both involve the invocation of supernatural forces against an enemy, seeking to damage them in some way. The rituals involved in the creation of both types appear often to have involved the inscription of a text on a lead tablet and the 
manipulation of lead figurines or dead animals (see Faraone 1991a-b; for differences between the two categories, see Versnel 2010). I then examine the ways in which two theories of ritual can aid in reviewing and perhaps recasting approaches to the role of the victim's agency in ancient magical practice. These theories emerge from two different approaches to the study of religion, one cognitive, and the other practice-based. One of the aims of this article is to explore how these may be used alongside one another. The article ends with some reflections on the implications that this may carry for scholarship on ancient magic and religion and the question of the nature of belief.

\section{How Does Magic Work?}

Roger Tomlin, in his masterful introduction to the analysis of the curse tablets from the Temple of Sulis Minerva at Bath, first establishes the evidence that the ancients did believe that this magical practice worked: "[T]he practice of inscribing them for two centuries ... implies that they did work. Or rather that they were believed to work; and, perhaps, that this belief was justified" (1988: 101-102). In trying to explain how these were understood to work, he turns to psychological or emotionalist explanations: the process of writing the tablet "removed intolerable tensions"; "allowed a transfer of emotions"; and, in general, "relieved the injured party's feelings; something at least had been done."7

In the Bath tablets, the crime that most commonly prompts the writing of the curse is that of stealing, but similar arguments have been made for the use of ancient magic in other spheres, perhaps most famously by Jack Winkler (1990), concerning attraction magic. In his acute analysis, Winkler argues that this ritual practice acted as a powerful therapy for those individuals (usually male) who were suffering the torments of eros. He explains how the person activating the spell would be able to imagine the victim as suffering the very agonies that he was experiencing because of his passion. This was a therapeutic process that created a new reality by effectively reversing existing circumstances: the result of writing the tablet for the spell-maker was a sense of control, as Winkler puts it, "over his own desperation"; the process of summoning "chthonic powers to do terrible things ... puts him in a role opposed to that of the erotic victim he 'actually' is" (1990: 91).

To evaluate this approach, we might briefly compare the argument put forward by Jonathan Z. Smith, which takes a similar approach to magic as the amelioration of anxiety, although it turns on an opposing paradigm. According to Smith, the ritual still models what should happen if everything were to go according to plan and all variables work as they should, but he argues that far from working with the model "like produces like," the principle is rather "unrealistic perfection" (1980: 127). Thus, where Winkler argues that magical rituals are intended to "compel the world through representation and manipulation" (1990: 91), Smith has argued that they express a realistic assessment of the fact "that the world cannot be compelled" (1980: 127). The therapeutic effect emerges for the ritualists not from their asserting control, but from re-understanding their lack of control.

Smith's approach has been criticized by Benjamin Ray, specifically in the context of its use to explain the bear rituals of the Koyukon of Alaska. Ray challenges the ethnographic basis for Smith's assessment of the bear ritual as a ritualized "perfect hunt"

\footnotetext{
7 Tomlin 1988: 101-102, quoting Henig 1984: 145 and Webster 1986: 136; see a discussion of emotionalist theories of magic in Sørensen 2007a: 24-30.
} 
and so unpicks his argument that it provides "symbolic compensation for a perceived failure" in the real world (1991: 159). Nevertheless, he also finds some broader insights in Smith's approach, observing how it differs markedly from the more widely held anthropological view that "ritual provides a rich and 'deep' interpretation of the world that the believer accepts as true and acts upon" and offers instead a radical interpretation of ritual as "an idealistic interpretation of the world" (1991: 164; as found in, for example, Geertz 1973: 112; Douglas 1966: 66). However, he asks, if that is the case, can those conducting the ritual be understood to believe their own words (or not) (1991: 171)? Ray argues against Smith that the language of the bear ritual must reveal the hunters' views of how things are; it provides the Koyukon perspective.

Winkler's approach can be described as starting from a similar basis to Smith's: he explains the potency of erotic magic as arising from the therapeutic side effects of conducting a ritual that imagines perfection. His approach has also prompted similar questions: for example, Faraone has taken issue with Winkler's portrayal of young male erotic spell-writers and his interpretation of the erotic spells (1999: 80-95). He argues that in fact only a minority of ancient spells express the passionate desperation for which Winkler argues, and in the case of those few, it remains unclear what their motivations may be. In light of similar spells written for social advancement or sexual conquest, Faraone has suggested that the erotic spells were written not in psychic pain but focused on hopes for the future, their effect not "one of healing or catharsis, but rather one of increased self-confidence" (1999: 84). This reception of both Winkler's and Smith's analyses are a reminder of the need to distinguish between the emic understanding that may be found in our evidence and the etic paradigms of scholarly discourse to which it may appear to conform. In the meantime, with regard to the larger argument of this article, we note that both these arguments and the critiques they provoke focus on the psychology of the perpetrators of magical ritual and pay little attention to the role of the target of magic, in either emic or etic terms.

However, as noted above, psychological insights have also been brought to bear on explanations of the target's behavior in particular by highlighting a perceived connection between target and spell-caster, such as the shared experience of a crime. Tomlin, for example, argues that the target of a curse of the kinds found at Bath, i.e., a thief, "might suspect that he had been cursed by his victim," provoking a psychosomatic illness (1988: 102-103; see also Ogden 1999: 82-85, esp. 84 on the possible manipulation of a potential victim's fear). In some contexts, there could have been explicit, material confirmation of such suspicions. There is evidence that so-called "prayers for justice," were pinned up in public places, ${ }^{8}$ but presumably, in these cases, less guilt would produce less of a psychological effect; moreover, as a mode of crime prevention, fear of such an affliction probably worked better against casual offenders than hardened criminals.

Where there seems to have been no specific event, such as a crime, to create an overt connection between two parties, we might imagine that such a link could emerge from existing social dynamics. Distrust, exacerbated by local gossip, could provoke someone suffering personal misfortune to identify the likely perpetrator of a suspected

\footnotetext{
8 See Versnel 1991a: 68-69, elaborated in Versnel 2009. The Knidian curses texts may have been displayed in this way (Newton 1862-1863), or they may have been inscribed on stone. On a stele in the Sanctuary of the Syrian Gods on Delos, one Theagenes asks for justice against a woman to whom he has lent money for her manumission and has not returned it; see Björck 1938: 30 n. 14; Versnel 1999: 141; Salvo 2012: 252-253.
} 
hostile attack, on the grounds that the aggressor must be motivated by malice or envy. ${ }^{9}$ The well-known confession inscriptions from ancient Asia Minor, although dealing with divine punishment rather than mortal hostility, provide powerful examples of such social processes of explanations of misfortune (Petzl 1994; Gordon 2004; Chaniotis 2004). Scholars have observed how in ancient Greek and Roman cultures such explanations that one had become the target of magical attack could work within a community as "a strategy to explain otherwise inexplicable failures" and as a way "to immunize themselves against possible negative social consequences" (Graf 1997b: 113; see, for example, Faraone 1989).

To illustrate a number of these explanatory approaches, we can turn to one of the most well-known ancient accounts of magical victimhood. This is from the autobiography of the fourth-century C.E. sophist and rhetor Libanius, who studied in Athens and taught in Constantinople and Nicomedia before settling in the city of his birth, Antioch, where he took up the post of sophist and ran a school of rhetoric. This is one of the few first-person accounts from antiquity of a magical attack that we possess. ${ }^{10}$ It is not intended that it should be taken as representative of all such experiences across antiquity - and it will be set in its specific context below. Nevertheless, it is notable that a number of its details align with briefer, third-person accounts of magical attack, including physical and mental pain, and the inability to speak (for an overview of these, see Faraone 1991a; Graf 1997a: $119,141-142)$. In addition, in support of this argument, some of the specific requests for suffering invoked against the victims of binding spells resonate with aspects of Libanius' description of his experience (Eidinow 2013: 146-156).

To set Libanius' account briefly in its context: the fourth century was a period of profound social, political, and spiritual tensions. Libanius was a pagan living in a world in which Christianity was in the ascendant, and the significance of particular ritual activities was contested across and between different social and religious groups (Sandwell 2007: 251-276). As a professional sophist, Libanius worked in a highly competitive, elite environment in which aggressive magical attack was widely feared, and accusations of magical practice abounded (Cribiore 2007: 90-95, 2013). Libanius' account is the creation of a highly literate and rhetorically skillful writer; moreover, it provides a commentary on a period of tremendous anxiety and stress for Libanius, resulting from both physical ailments and political dangers (including accusations of magic against his colleagues; see Norman 2000: 124). This might lead modern readers to doubt its value as a historical document offering insight into general perceptions of the experience of magical victimhood, its historical value undermined by both Libanius' artistry and his personal agenda. But I would argue that these aspects may increase its potential for our purposes. It seems plausible that in attempting to persuade his reader of the reality of his suffering, Libanius would have drawn on widely accepted cultural models of the experience of a magical attack and used his literary skills to evoke its details.

Libanius' description offers insights into his own mental and emotional reactions, and includes observations that allow us to glimpse some of the wider social processes surrounding the event (Orations 1.245-249). He recounts how he became unsociable: he is unable to visit the baths or go to dinner. He cannot work: he turns away from his books, avoids composing his own work, and cannot declaim. There are physical and associated

\footnotetext{
${ }^{9}$ See Stewart and Strathern 2004 for illuminating anthropological studies. For discussion of some ancient examples, see Gordon 1999; Bryen and Wypustek 2009.

10 For another example, dating to 197 C.E., see the series of petitions filed by Gemellus Horion, a landholder in Karanis, see P.Mich VI 423-424; Bryen and Wypustek 2009.
} 
emotional or mental symptoms: he is crippled by physical pain, is fearful, and wishes to die. Without making an overt statement or accusation, he reveals that his own explanations of these events tend towards suspicion of a magical attack: he has dreams that seem to portend "spells, incantations, and the hostility of sorcerers" (Orations 1.245). ${ }^{11}$ Moreover, his misgivings are probably exacerbated by what other people are saying. Only a brief glimpse of this is given in Libanius' cursory mentions of conversations or general gossip: for example, he describes how, in the early stages of his illness, his "friends kept urging me, and each other too, to prosecute certain individuals who were rumoured to be responsible for this" (Orations 1.248). Libanius restrains them, "telling them to offer up prayers rather than to have folk arrested for secret machinations" (Orations 1.248). And when he is very ill, he tells us, there were people "prophesying that I would be dead before morning, and, in fact, in other cities it was said that I was dead already" (Orations 1.247). These narrative seeds are well sown: all these implicit suspicions are borne out once a dead and misshapen chameleon is dug out of his study wall. This is clearly a magical attack: the head of the animal has been tucked between its hind legs, with one front leg missing while the other is covering its mouth as if to silence it (Orations 1.249).

In our attempt to understand what Libanius, and others like him, may have experienced, the psychological explanations listed above are extremely useful. We can set him in a context in which the fear of magical attack was pervasive. Not only did Libanius have plenty of rivals; some of them, we know, accused him of practicing magic against them, especially in contexts where he had beaten them in rhetorical competitions (Orations 1.43; cf. Brown 1970). Once he begins to suffer symptoms that prevent him from working or teaching, it is very convincing to argue that he was probably looking for an explanation, for others and for himself, to help soothe the social pressures of not performing well (see, for example, Faraone 1991a: 15-16; Graf 1997a: 164-165; Ogden 1999: 27-28). Indeed, from what he says, it is apparent that others around him easily took up such an explanation and knew enough about Libanius' relationships - those with whom he competed, for example - to be able to pinpoint likely perpetrators.

Such analyses offer crucial insights into some of the social dynamics related to the psychology of victimhood. Nevertheless, they still tend towards an implicit view of victims of magic as simply reactive or passive. Where the ancients saw victims of magical attack, these analyses depict victims of the social dynamics that we have come to understand "magic" to represent - be these the dynamics of power, politics, and/or social control. In contrast, I want to suggest instead that we can find grounds to describe these victims as themselves exhibiting agency and, moreover, argue that their agency helped to generate the culturally shared perception of the nature and role of "magic."

\section{Ritual Form and Ritual Agency}

As Gordon has observed of ancient Greco-Roman magic, while "we have no hope of examining in detail the construction of magical rituals" (2008: 147), we can still use the notion of magical action as symbolic to examine the social sites of magic. In general, such investigations tend to focus on aspects relating to the magical practitioner: Gordon's own list includes, for example, social contexts, the question of the place of "magical healing," the kinds of people who become magicians, and the hierarchy of roles and capacities. This article suggests that we may also identify the victim himself or herself as one of those

11 All translations of Libanius' Orations are from Norman 1992 unless otherwise noted. 
sites; but this raises the question of a suitable methodology. As noted above, analysis of the power of ancient magical practitioners has often focused on the nature of the performative power of ritual speech, which brings us to Stanley Tambiah's approach to ritual. He has described this as a "culturally constructed system of symbolic communication ... constituted of patterned and ordered sequences of words and acts, often expressed in multiple media, whose content and arrangement are characterized in varying degree by formality (conventionality), stereotype (rigidity), condensation (fusion), and redundancy (repetition)" (1979: 119). As this indicates, Tambiah at first gives equal weight to "sequences of words and acts", but, while recognizing the need for both, the focus of his analysis largely comes to rest on the nature of the performative power of ritual speech. In contrast, the ancient victims of magical attack, for the most part, offer us few equivalent verbal resources; nevertheless, these fundamental concepts of communication, performativity, and the "sequences of words and acts" are also significant in considering the ritual agency of the victim. Here, I want to focus in particular on the role of sequences of "acts" as a form of communication.

My approach to the ritual agency of "victims" of magic draws on the idea of the ritual form, using the theory developed by Robert McCauley and E. Thomas Lawson to analyze perceptions of the performance of religious rituals. ${ }^{12}$ The theory builds on competence theories in the field of linguistics to explain the implicit acquisition of ritual systems and posits an "action representation system" to explain conceptions of ritual action. Thus, the ritual form comprises three fundamental roles - agent, act (by means of instruments), and patient. Each of the three roles may be represented as related to superhuman agency; McCauley and Lawson call this the Principle of Superhuman Agency, or PSA (see McCauley and Lawson 2002: 26-27), which involves culturally postulated superhuman (hereafter CPS) agents, that is, some kind of agent with greater than mortal powers that is specific to a particular culture. Such CPS-agency may be linked to the mortal agent of the ritual, like a priest; or CPS-agents may be the patients of a ritual, such as the divine recipients of sacrifice; or they may transform the instrument of the ritual, as when holy water is transformed from ordinary water because of such a connection.

McCauley and Lawson (2002: 8) stress two key aspects: first, that their approach comprises a theory of ritual competence, that is, "a systematic account, which describes participants' knowledge about the acceptability of ritual performances ... it is nota theory of ritual acts" (Lawson and McCauley 1990: 77; italics original). Thus, rituals are represented as efficacious actions because they exploit ordinary types of actions, which are recognized using everyday processes of social cognition (McCauley and Lawson 2002: $8,11)$. Once the three roles of ritual are identified, then participants begin to generate inferences about the intention behind a ritual and its likely efficacy (McCauley and Lawson 2002: 12-14). Although different participants may come to very different conclusions about a ritual's meaning, the theory argues that this does not affect the shared fundamental knowledge of the ritual form.

The second aspect is that the role of CPS-agents is crucial for understanding the properties and powers attributed to ritual, and it is important where they appear. There may of course be more than one connection to a CPS-agent in any ritual, and it is important to identify how closely the CPS-agent is related in each case. This is what McCauley and Lawson call the Principle of Superhuman Immediacy, or PSI, which states that "the number of enabling rituals required to connect some element in the current

${ }^{12}$ Although I will cite material from their earlier formulation of this theory (in Lawson and McCauley 1990), this analysis employs the terminology of its later presentation (in McCauley and Lawson 2002). 
ritual with an entry for a CPS-agent determines that entry's proximity to the current ritual" (McCauley and Lawson 2002: 27). This can be illustrated with the example of an ancient binding-spell ritual, in which a professional spell-writer may simply assert a close relationship to a CPS-agent (no ritual appears to have been necessary to support this claim); whereas, for the CPS-agent to be cast as a patient in this ritual, a sacrifice is necessary; and finally, for the instrument of the spell (for example, a dead animal or a lead tablet on which the spell is scratched) to be connected to CPS-agency, a number of enabling rituals are required.

Justin Barrett has summarized this theory as defining "religious rituals as acts in which someone does something to someone or something in order to bring about some non-natural consequence by virtue of appeal to superhuman agency" (2002: 184). His précis emphasizes the importance of the ascription and recognition of agency, both CPSagency and mortal agency — and the relationship between them. Indeed, McCauley and Lawson argue that a ritual will acquire certain particular qualities when it is a "specialagent ritual," that is, when a god or representative of a god is in the agency slot (see McCauley and Lawson 2002: 187-202). This type of ritual is more likely to be marked with sensory pageantry, rousing emotional responses. While it is unlikely to be repeated, it is perceived to have more permanence - in the sense that its effects must be ritually removed, that is, they will not simply wear off. Moreover, they argue, changes in agents matter far more to participants than changes made to other elements of a ritual (McCauley and Lawson 2002: 32-33, citing Barrett and Lawson 2001). Barrett has further developed this claim, demonstrating that it turns on the presumed nature of the CPS-agent involved: "observers will judge that having the proper sort of performer - and intentional agent - is more important than having the proper sort of action for a religious ritual to be successful, provided the superhuman agent appealed to has access to the intentions of the performer apart from the performance itself" (2002: 191; italics original). This, in turn, raises a final important point about the network of beliefs into which a ritual is integrated. McCauley and Lawson argue that a crucial aspect of understanding the particular involvement of superhuman agents in any ritual is tacit knowledge of the network of rituals that structure it (2002: 27-28). But perhaps more importantly here, as Jesper Sørensen has argued, are the perceived connections "to larger conceptual and institutional networks, and thus to both myth and dogma" (2007b: 295). ${ }^{13}$

This approach can be applied to the example of Libanius so as to nuance our understanding of this event. Libanius and his friends identify an association between what are two completely separate events - an illness and the discovery of a dead chameleon. In fact, there is no evidence that the chameleon was part of a magical ritual with Libanius as its target. Libanius and those around him create a causal link between the two, interpreting the chameleon as cause of the preceding illness. In part, this occurs because of the temporal contiguity of the two events: the illness is understood as an indexical sign of the chameleon. But this in turn depends on cultural knowledge of the ritual form of such a magical attack (Sørensen 2005: 105). The text describes how Libanius and his friends use their knowledge of the ritual form involved in the creation of a binding spell, drawing on a larger network of ritual and social knowledge, to explain Libanius' suffering in terms of the experience of a victim of magic. Indeed, although the discovery of the chameleon appears to bring to an end some of the psychological pressure on Libanius, by providing an explanation and enabling some action to be taken, there is

${ }^{13}$ See also Sørensen 2005 for an analysis of the hermeneutic strategies involved in ritual interpretation. 
evidence that it also confirmed Libanius' fears that he had been the target of magical attack by an anonymous enemy (Orations 36; see Norman 2000: 124; Eidinow 2015: 160).

This gives us some insight into the cognitive processes that may have underpinned attributions of a magical attack. But if we make Libanius' actions the focus of our analysis rather than the byproduct, the theory of ritual form can also lead us to identify a further set of ritual actions in his description. As noted, although Libanius expresses fears of a previous ritual (and although with our knowledge of the ritual form of a binding spell, we are also tempted to assume one), as far as we know, there have in fact been no previous enabling rituals. Indeed, rather than being the fearful target or "patient" of an (imagined) ritual created by an anonymous, unseen practitioner, I want to argue that this so-called victim is himself actively engaged, in concert with those around him, in creating a separate ritual. In terms of the theory of ritual form, Libanius is himself the "special agent" in a ritualizing process that he describes in his text, one in which his fear, his activities, and the interactions between himself and his friends are all generative elements.

\section{The Victim as Ritualizing Agent}

In suggesting that we can identify in this set of actions a distinct ritual form, I am drawing on Catherine Bell's approach to "ritualization." The experiences of suffering that Libanius undergoes, or of the kinds of misfortunes that our sources indicate might lead to similar suspicions that one had been a target of magical attack, did not involve ways of acting that were wholly different from non-magical experiences. Rather, they were ritualized, recognized as "a way of acting that specifically establishes a privileged contrast, differentiating itself as more important or powerful" (Bell 1992: 90). The development of this differentiation, the process of this ritualization, was complex. In part, it drew on the recognition of ritual form, as described above, and the resonance of the victim's experiences with the nexus of cultural schemas that were understood to comprise the experience of magical victimhood. In part, it comprised emergent strategies of ritualization, for example, in the case of Libanius, both in the interactions between him and his friends, as he describes them, and also those that occurred and continue to occur between him and the reader.

The terms "strategies" and "emergent" underline two key aspects of this activity that need further explanation. First, that of strategies: by setting off his experiences as important and distinct from others, Libanius engages in the reshaping of his position in a social - and cosmological - context. In doing so, he redescribes the relations not only between other mortals (himself, his friends, the larger community of people who are aware of the events through gossip), but also between mortals and gods. At issue in all these relations are questions of power - who has the power to harm, to protect, to endure, to win? We can see in these activities how, as Bell puts it, "ritual practices are themselves the very production and negotiation of power relations" (1992: 196). To return to Ortner's categories of agency, the victim Libanius can be described as exercising in this episode an agency of power. In the analysis above, I have identified some of the ways in which Libanius does this, and this leads to my use of the term emergent. By introducing this, I mean to highlight the creative, almost improvisatory, role of the victim, that is, within culturally defined strictures. ${ }^{14}$ Claude Levi-Strauss's use of the bricoleur

14 Cf. Frederick Naerebout on ritual dance; he captures this ambiguity in his statement that "[p]ublic events and all ritualized behavior that goes with it are realized in particular performance, and they are changing from the one performance to the next." (2006: 44). 
(1962) to evoke the operation of mythical thought has been employed successfully to describe the activities of a charismatic and creative spell-maker (Johnston 2002: 167). I suggest here that a "victim" of magical action was just as, and similarly, resourceful. Socalled "victims" like Libanius were calling on ritual knowledge comprising cognitive schemas and scripts for particular ritual contexts and expressing that knowledge through a shared "vocabulary" of action.

This still allowed for some extemporization in interpretation and responses, both by the individuals directly involved and their surrounding social group. I made reference earlier in this article to the artistry of Libanius, in terms of his literary skills. I return to it here - but now in consideration of his report as evidence for his skills in the development of ritualized action. In his account, we see how Libanius assembles a list of "symptoms" that conform to the kind of suffering understood to be experienced in a magical attack. The process of developing these symptoms and attributing them to a magical attack is interactive: we see how Libanius' friends, and the wider community, respond to his distress. They recognize the cause of his suffering - even, perhaps the likely perpetrator - and urge legal action; Libanius restrains them and asks instead for prayers - a ritual act within a ritualized context. Not only is recognition of what is happening to him shared, but so is the process by which that recognition develops. The discovery of a material cause of what is happening - the chameleon - occurs just as the request for prayers is made in the text, as if divinely sent. So far, I have emphasized events within the text, but this last observation also prompts us to consider the text itself as a key element by which Libanius was ritualizing his experience. His interaction with an audience went beyond the community of friends that he described to the community of readers that he was addressing: not only they, but we, too, are co-creators in the ritualization of victimhood.

As this suggests, the generation of the role of the victim was a ritualized act; it organized the local social world and was, in turn, organized by that local social world. It not only employed shared knowledge of institutional structures, but also created them; and, as Bell describes, it both drew on relationships of power and helped to generate them. ${ }^{15}$ But this creative process not only manipulated mortal relationships; it also worked in a similar way with supernatural forces. Jesper Sørensen has argued that "ritualized behaviour in producing cues ... makes the evocation of existing culturally transmitted superhuman agents highly relevant or, alternatively, lead[s] to the production of new superhuman agents" (2007b: 297). Libanius invoked the gods, but, equally, it was his own sequence of actions and words, interacting with those of his friends and the larger social world, which generated the presence of supernatural forces.

With this final point, I want to draw particular attention to the role of the body in this process of ritualization. Although Libanius is suffering physically, our focus on the verbal description of his experiences (both written and reported) means that it is easy to lose sight of the significance of his body in this process. The analysis of ritual performativity as physical expression has been a rich inspiration for scholarship on several different aspects of ancient culture, including, for a long time, ancient Greek religion. ${ }^{16}$ But, as noted earlier in this article, for understandable reasons, most previous

\footnotetext{
${ }^{15}$ As Bell puts it, "Relationships of power are drawn from the social body and then reappropriated by the social body as experience" (1992: 207).

16 A sample, with no claim to be comprehensive, includes Calame 1977; Lonsdale 1993; Versnel 1993; Burkert 1996; Naerebout 1997; Bierl 2009. In work on the role of the body in the performance of religious rituals within sacred space, along with the interaction of ritual and architectural spaces has received greater focus, see, e.g., Mylonopoulos 2006; Naerebout 2006.
} 
scholarship on ancient magic has focused on the significance of words, in particular, speech-act theory, which puts the emphasis on language, especially the categories of performative utterances and illocutionary force. ${ }^{17}$

An initial step in reintroducing the body to the discussion of ancient magic may be to consider the embodied nature of the ritualization enacted by victims of magic: the suffering that they endure is often, if not usually, physical. The ritual of magical victimhood is, at least at first, expressed through "a logic embodied in the physical movements of the body, and thereby lodged beyond the grasp of consciousness and articulation" (Bell 1992: 99). This evocation of implicit knowledge calls to mind the intuitive recognition described by the theory of ritual form; the "socialized body" operating within a "pre-existing set of structures" recalls the "larger conceptual and institutional networks" of the development of this theory described above (Bell 1992: 220; Sørensen 2007b: 295). And, as noted above, this process is importantly dynamic and creative: an individual claiming to be, or to be described as, a victim of ancient magic was, through this physical communication, in the context of his social group, himself or herself recreating existing cultural relationships of power and authority, generating, maintaining, and reshaping ritual knowledge.

\section{The Relational Dynamics of Magic}

This article has used the theories of ritual form and of ritualization with the intention of developing current analyses of ancient magic by clarifying the social, physical, and cognitive processes - and their interactions - of those portrayed as victims of magic. It has argued that these figures, previously treated as passive or psychologically troubled, are in fact depicted as themselves deploying a culturally recognizable embodied ritualizing practice. They can, therefore, be described in Ortner's terms, as demonstrating an agency of power. In a community in which magical aggression was both practiced and feared, the perceived potency of "magic" was not rooted simply in the (linguistic) activities of the creator of a spell. Instead, accounts of the behavior of individual targets of magic (either stipulated in spells or documented anecdotally) suggest that, concurrently, the ritualization of physical experiences by so-called victims also manufactured the phenomenon of "magic." The perception of magical power, the experience of supernatural presence, was thus co-created by ritual practitioners and their so-called victims - the agency of one reinforcing the agency of the other and vice versa.

For this ritualization to be effective, both ritual practitioners and victims drew on cultural knowledge - both their own and that of the broader networks of social relations within which they were integrated. The interaction of social and cultural structures with individual perception and action is a crucial aspect of this analysis. In a context of scholarship on ancient Greco-Roman religion in which the place of the individual as opposed to the group and the role of ritual as opposed to belief remain topics of debate (see Versnel 2011, esp. 122-123), this analysis moves away from these dichotomies.

17 Others have noted this dichotomy: e.g., Smith noted that the adoption of speech-act theory may be a way of trying to overcome it, but expressed uncertainty as to whether "the generating distinction between constatives and performatives is not a reinscription of the same duality" (2002: 90); in the same volume, Versnel describes "twin strategies widely applied in this type of medical magic ... These two strategies consist of ritual action on the hand and ritual words on the other" and asks the reader to bear in mind that "words and deeds are often two complementary and inseparable parts of one ritual process" (2002: 107). 
Instead, this article has drawn attention to the ways in which, in a number of respects, the perception of magical power can be described as emerging from relational dynamics. Mind and body, individual and group, individual and broader culture all interacted in the development of ancient ritual and belief. As the example of Libanius has illustrated, it was the ritualized and embodied interrelationship of individual and society that generated, continually, the perceived presence of the supernatural and belief in the power of "magic."

\section{References}

Barrett, Justin L. 2002. "Smart Gods, Dumb Gods, and the Role of Social Cognition in Structuring Ritual Intuitions." Journal of Cognition and Culture 2(3): 183-193.

Barrett, Justin L., and E. Thomas Lawson. 2001. "Ritual Intuitions: Cognitive Contributions to Judgments and Ritual Efficacy." Journal of Cognition and Culture 1(2): 183-201.

Bell, Catherine. 1992. Ritual Theory, Ritual Practice. Oxford: Oxford University Press.

Betegh, Gábor. 2004. The Derveni Papyrus: Cosmology, Theology, and Interpretation. Cambridge: Cambridge University Press.

Bierl, Anton. 2009. Ritual and Performativity: The Chorus in Old Comedy. (Hellenic Studies Series, 20). Cambridge, Mass.: Harvard University Press.

Björck, Gudmund. 1938. Der Fluch des Christen Sabinus: Papyrus Upsaliensis 8. Uppsala: Almqvist and Wiksell.

Boschung, Dietrich, and Jan Bremmer. 2015. The Materiality of Magic. (Morphomata, 20). Paderborn: Wilhelm Fink.

Brown, Peter. 1970. "Sorcery, Demons, and the Rise of Christianity from Late Antiquity into the Middle Ages." In Mary Douglas (ed.), Witchcraft: Confessions and Accusations, London: Tavistock, 17-45.

Bryen, Ari Z., and Andrzej Wypustek. 2009. “Gemellus' Evil Eyes (P.Mich. VI 423-424).” Greek, Roman, and Byzantine Studies 49: 535-55.

Burkert, Walter. 1996. Creation of the Sacred: Tracks of Biology in Early Religions. Cambridge, Mass.: Harvard University Press.

Burrus, Virginia. 1995. The Making of a Heretic: Gender, Authority, and the Priscillianist Controversy. (Transformation of the Classical Heritage, 24). Berkeley: University of California Press.

Calame, Claude. 1977. Les chours de jeunes filles en Grèce archä̈que. 2 vols. (Filologia e critica, 20-21). Rome: Edizioni dell'Ateneo and Bizzarri.

Carastro, Marcello. 2006. La Cité des mages: penser la magie en Grèce ancienne. Grenoble: Jérôme Millon.

Chaniotis, Angelos. 2004. "Under the Watchful Eyes of the Gods: Aspects of Divine Justice in Hellenistic and Roman Asia Minor." In Stephen Colvin (ed.), The Greco-Roman East: Politics, Culture, Society, (Yale Classical Studies, 31), Cambridge: Cambridge University Press, 1-43.

Collins, Derek. 2008. Magic in the Ancient Greek World. (Blackwell Ancient Religions). Malden, Mass.: Blackwell.

Cooper, Kate. 1996. The Virgin and the Bride: Idealized Womanhood in Late Antiquity. Cambridge, Mass.: Harvard University Press.

Cribiore, Rafaella. 2007. The School of Libanius in Late Antique Antioch. Princeton: Princeton University Press.

- - - 2013. Libanius the Sophist: Rhetoric, Reality, and Religion in the Fourth Century. Ithaca, N.Y.: Cornell University Press. 
Curbera, Jaime B. 1999. "Maternal Lineage in Greek Magical Texts.” In David R. Jordan, Hugo Montgomery, and Einar Thomassen (eds.), The World of Ancient Magic: Papers from the First International Samson Eitrem Seminar at the Norwegian Institute at Athens 4-8 May 1997, Bergen: The Norwegian Institute at Athens, 195-203.

D’Angelo, Mary Rose. 1990. "Women in Luke-Acts: A Redactional View." Journal of Biblical Literature 109(3): 441-461.

Dickie, Matthew W. 2001. Magic and Magicians in the Greco-Roman World. London: Routledge.

Douglas, Mary. 1966. Purity and Danger: An Analysis of Concepts of Pollution and Taboo. London: Routledge and Kegan Paul.

-_- (ed.). 1970. Witchcraft: Confessions and Accusations. London: Tavistock.

Eidinow, Esther. 2013 [2007]. Oracles, Curses, and Risk among the Ancient Greeks. Oxford: Oxford University Press.

-——. 2015. Envy, Poison, and Death: Women on Trial in Classical Athens. Oxford: Oxford University Press.

- — . Forthcoming. "'A Devotee and a Champion': Re-interpreting the Female 'Victims' of Magic in Early Christian Texts." In Matthew P. Dillon, Esther Eidinow, and Lisa Maurizio (eds.), Women's Ritual Competence in the Greco-Roman Mediterranean, Farnham: Ashgate, 213-228.

Evans-Pritchard, Edward Evans. 1937. Witchcraft, Oracles, and Magic among the Azande. Oxford: Clarendon Press.

Faraone, Christopher A. 1989. "An Accusation of Magic in Classical Athens (Ar. Wasps 946-48)." Transactions of the American Philological Association 119: 149-160.

-_- 1991a "The Agonistic Context of Early Greek Binding Spells." In Christopher Faraone and Dirk Obbink (eds.), Magika Hiera: Ancient Greek Magic and Religion, Oxford: Oxford University Press, 3-33.

-__. 1991b. "Binding and Burying the Forces of Evil: The Defensive Use of 'Voodoo Dolls' in Ancient Greece." Classical Antiquity 10 (2): 165-205.

-_- 1999. Ancient Greek Love Magic. Cambridge, Mass.: Harvard University Press.

Favret-Saada, Jeanne. 1980. Deadly Words: Witchcraft in the Bocage. Cambridge: Cambridge University Press.

Flower, Michael. 2008. The Seer in Ancient Greece. Berkeley: University of California Press.

Frankfurter, David. 1995. "Narrating Power: The Theory and Practice of the Magical Historiola in Magical Spells." In Marvin Meyer and Paul Mirecki (eds.), Ancient Magic and Ritual Power, Leiden: Brill, 457-476.

- - - 1997. "Ritual Expertise in Roman Egypt and the Problem of the Category 'Magician.'” In Peter Schäfer and Hans Kippenberg (eds.), Envisioning Magic: A Princeton Seminar and Symposium, Leiden: Brill, 115-135.

—_- 2002. "Dynamics of Ritual Expertise in Antiquity and Beyond: Towards a New Taxonomy of 'Magicians.'” In Paul Mirecki and Marvin Meyer (eds.), Magic and Ritual in the Ancient World, Leiden: Brill, 159-178.

Frazer, James G. 1922. The Golden Bough: A Study in Magic and Religion. London: Macmillan.

Geertz, Clifford. 1973. "Religion as a Cultural System." In The Interpretation of Cultures. New York: Basic Books, Inc., 87-125.

Giordano, Manuela. 1999. La parola efficace: Maledizioni, giuramenti e benedizioni nella Grecia arcaica. Pisa: Istituti Editoriali E Poligrafici Internazionali. 
Gordon, Richard. 1999. "Imagining Greek and Roman Magic." In Valerie Flint (ed.), Witchcraft and Magic in Europe: Ancient Greece and Rome, London: The Athlone Press, 159-275.

- - - 2004. "Raising a Sceptre: Confession-Narratives from Lydia and Phrygia." Journal of Roman Archaeology 17: 177-196.

———. 2008. "Talking of Magic." In John Petropoulos (ed.), Greek Magic: Ancient, Medieval and Modern, Abingdon and New York: Routledge, 139--149.

Graf, Fritz. 1995. "Excluding the Charming: The Development of the Greek Concept of Magic." In Marvin Meyer and Paul Mirecki (eds.), Ancient Magic and Ritual Power, Leiden: Brill, 29-42.

-_- 1997a. Magic in the Ancient World. Franklin Philip (trans.). Cambridge, Mass: Harvard University Press.

———. 1997b. "How to Cope with a Difficult Life: A View of Ancient Magic." In Peter Schäfer and Hans Kippenberg (eds.), Envisioning Magic: A Princeton Seminar and Symposium, Leiden: Brill, 93-114.

Henig, Martin. 1984. Religion in Roman Britain. London: Batsford.

Hutton, Ronald. 2004. "Anthropological and Historical Approaches to Witchcraft: Potential for a New Collaboration?" The Historical Journal 47(2): 413-434.

Johnston, Sarah Iles. 2002. "Sacrifice in the Greek Magical Papyri." In Paul Mirecki and Marvin Meyer (eds.), Magic and Ritual in the Ancient World, Leiden: Brill, 344358.

Kingsley, Peter. 1995. Ancient Philosophy, Mystery, and Magic: Empedocles and Pythagorean Tradition. Oxford: Clarendon Press.

Laskaris, Julie. 2002. The Art is Long: On Sacred Disease and the Scientific Tradition. Leiden: Brill.

Lawson, E. Thomas, and Robert N. McCauley. 1990. Rethinking Religion: Connecting Cognition and Culture. Oxford: Oxford University Press.

Lévi-Strauss, Claude. 1962. La pensée sauvage. Paris: Plon.

LiDonnici, Lynn R. 2002. "Beans, Fleawort, and the Blood of a Hamadryas Baboon: Recipe Ingredients in Greco-Roman Magical Materials." In Paul Mirecki and Marvin Meyer (eds.), Magic and Ritual in the Ancient World, Leiden: Brill, 359-377.

Lloyd, Geoffrey. 1979. Magic, Reason, and Experience: Studies in the Origin and Development of Greek Science. Cambridge: Cambridge University Press.

Lonsdale, Steven H. 1993. Dance and Ritual Play in Greek Religion. Baltimore: The Johns Hopkins University Press.

McCauley, Robert N., and E. Thomas Lawson. 2002. Bringing Ritual to Mind: Psychological Foundations of Cultural Forms. Cambridge: Cambridge University Press.

Mylonopoulos, Joannis. 2006. "Greek Sanctuaries as Places of Communication through Rituals: An Archaeological Perspective.” In Eftychia Stavrianopoulou (ed.), Ritual and Communication in the Graeco-Roman World, (Kernos Supplément, 16), Liège: Presses universitaires de Liège, 69-110.

Naerebout, Frederick. G. 1997. Attractive Performances: Ancient Greek Dance: Three Preliminary Studies. Amsterdam: Gieben.

———. 2006. "Moving Events: Dance at Public Events in the Ancient Greek World: Thinking through its Implications." In Eftychia Stavrianopoulou (ed.), Ritual and Communication in the Graeco-Roman World, (Kernos Supplément, 16), Liège: Presses universitaires de Liège, 37-67.

Newton, Charles T., with assistance from by R. P. Pullan. 1862-1863. History of Discoveries at Halicarnassus, Cnidus and Branchidae. 2 vols. London: Day and Son. 
Norman, A. F. (ed. and trans.). 1992. Libanius: Autobiography and Selected Letters. (Loeb Classical Library, 478). Cambridge, Mass.: Harvard University Press.

- - - 2000. Antioch as a Centre of Hellenic Culture as Observed by Libanius. Liverpool: Liverpool University Press.

Ogden, Daniel. 1999. "Binding Spells: Curse Tablets and Voodoo Dolls in the Greek and Roman Worlds." In Valerie Flint (ed.), Witchcraft and Magic in Europe: Ancient Greece and Rome, London: The Athlone Press, 3-90.

Ortner, Sherry. 2006. Anthropology and Social Theory: Culture, Power, and the Acting Subject. Durham, N.C.: Duke University Press.

Otto, Bernd-Christian. 2011. Magie: Rezeptions- und diskursgeschichtliche Analysen von der Antike bis zur Neuzeit. (Religionsgeschichtliche Versuche und Vorarbeiten, 57). Berlin: De Gruyter.

Petzl, Georg. 1994. Die Beichtinschriften Westkleinasiens. (Epigraphica Anatolica, 22). Bonn: Habelt.

Prins, Johanna Henrica (Yopie). 1991. “The Power of the Speech Act: Aeschylus' Furies and Their Binding Song." Arethusa 24(2): 177-194.

Ray, Benjamin C. 1991. "Koyukon Bear Party and the 'Bare Facts' of Ritual." Numen 38(2): 151-176.

Salvo, Irene. 2012. “Sweet Revenge: Emotional Factors in 'Prayers for Justice."' In Angelos Chaniotis (ed.), Unveiling Emotions: Sources and Methods for the Study of Emotions in the Greek World, Stuttgart: Franz Steiner Verlag, 235-266.

Sandwell, Isabella. 2007. Religious Identity in Late Antiquity: Greeks, Jews and Christians in Antioch. Cambridge: Cambridge University Press.

Schnoebelen, Jill. 2009. Witchcraft Allegations, Refugee Protection, and Human Rights: A Review of the Evidence. (New Issues In Refugee Research, Research Paper 169). Geneva: United Nations High Commissioner for Refugees.

Smith, Jonathan Z. 1980. "The Bare Facts of Ritual.” History of Religions 20(1-2): 112127.

- - - 2002. "Great Scott! Thought and Action One More Time." In Paul Mirecki and Marvin Meyer (eds.), Magic and Ritual in the Ancient World, Leiden: Brill, 73-91.

Sørensen, Jesper. 2005. "The Problem of Magic — Or How Gibberish Becomes Efficacious Action." Recherches semiotiques/Semiotic Inquiry 25(1-2): 93-117.

-_- 2007a. A Cognitive Theory of Magic. Lanham, Md.: AltaMira Press.

—_- 2007b. "Acts that Work: A Cognitive Approach to Ritual Agency." Method and Theory in the Study of Religion 19(3): 281-300.

Stewart, Pamela J., and Andrew Strathern. 2004. Witchcraft, Sorcery, Rumors, and Gossip. Cambridge: Cambridge University Press.

Stratton, Kimberley. 2007. "The Rhetoric of 'Magic' in Early Christian Discourse: Gender, Power and the Construction of 'Heresy.'” In Todd Penner and Caroline Vander Stichele (eds.), Mapping Gender in Ancient Religious Discourses, Leiden: Brill, 89114.

Tambiah, Stanley J. 1968. “The Magical Power of Words.” Man 3(2): 175-208.

- - 1979. "A Performative Approach to Ritual." Proceedings of the British Academy 65: 113-169.

Tomlin, Roger S. 0. 1988. "The Curse Tablets." In Barry Cunliffe (ed.), The Temple of Sulis Minerva at Bath, Vol. 2: The Finds from the Sacred Spring, Oxford: Oxford University Committee for Archaeology, 59-277. 
Versnel, Hendrik S. 1991a. "Beyond Cursing: The Appeal to Justice in Judicial Prayers." In Christopher A. Faraone and Dirk Obbink (eds.), Magika Hiera: Ancient Greek Magic and Religion, Oxford: Oxford University Press, 60-106.

1991b. "Some Reflections on the Relationship Magic-Religion." Numen 38(2): 177-197.

- - - 1993. Inconsistencies in Greek and Roman Religion II: Transition and Reversal in Myth and Ritual. (Studies in Greek and Roman Religion, 6.II). Leiden: Brill.

- - - 1999. "Punish Those Who Rejoice in Our Misery': On Curse Tablets and Schadenfreude." In David R. Jordan, Hugo Montgomery, and Einar Thomassen (eds.), The World of Ancient Magic: Papers from the First International Samson Eitrem Seminar at the Norwegian Institute at Athens, 4-8 May 1997, Bergen: The Norwegian Institute at Athens, 125-162.

- - - 2002. "The Poetics of the Magical Charm. An Essay in the Power of Words." In Paul Mirecki and Marvin Meyer (eds.), Magic and Ritual in the Ancient World, Leiden: Brill, 105-158.

- - - 2010. "Prayers for Justice, East and West: New Finds and Publications since 1990." In Richard Gordon and Francisco Marco (eds.), Magical Practice in the Latin West: Papers from the International Conference held at the University of Zaragoza, 30th Sept. - 1st Oct. 2005, Leiden: Brill, 275-356.

-_- 2011. Coping with the Gods: Wayward Readings in Greek Theology. Leiden: Brill. Webster, G. A. 1986. The British Celts and Their Gods under Rome. London: Batsford.

Winkler, John J. 1990. The Constraints of Desire: The Anthropology of Sex and Gender in Ancient Greece. New York and London: Routledge.

Wittgenstein, Ludwig. 1967. "Bemerkungen über Frazers 'The Golden Bough.'” Synthese 17(1): 233-253. 